\title{
All systems go in Britain
}

IT has been a fortnight of activity at the business end of biotechnology in Britain. First Genentech, the Californian company, was granted a British patent for its tissue plasminogen activator (TPA), which is expected to find a place in the treatment of myocardial infarction. Then the British pharmaceutical company Wellcome plc, while awaiting Genentech's announced intention to file suit against Wellcome for infringement of the newly granted TPA patent, set in motion an attempt to revoke the patent. And finally, the first British licences for a clinical use of interferon were granted.

The interferon licences are less of a coup than they might seem, since they are only for the treatment of hairy-cell leukaemia, of which there are fewer than 100 new cases a year in Britain. Interestingly, the Committee on Safety of Medicines, which grants the licences, has chosen not to discriminate between Wellcome's interferon (trade name Wellferon), which is purified from a cultured cancer cell line and is a mixture of the many slightly different $\alpha$-interferons, and Intron $\mathrm{A}$, which is a single $\alpha$-interferon produced in bacteria by recombinant DNA technology by Schering-Plough (the licence goes to the company's British subsidiary Kirby-Warrick Pharmaceuticals Limited). Hoffmann-La Roche has

\section{Swiss prize shared}

Désıré Collen of the University of Louvain, Luc Montagnier of the Institut Pasteur and Michael Berridge of the University of Cambridge have shared this year's $£ 600,000$ prize awarded by the Louis Jeantet Foundation for Medicine.

The prize, named after a resident of Geneva who died in 1981, is awarded annually to up to three "outstanding and productive research workers" to provide them "with substantial funds to pursue their researches".

Collen, whose work on the mechanisms of thrombus dispersal forms the basis of the British patent for tissue plasminogen activator, awarded to Genentech two weeks ago, will use the prize money to apply genetic engineering to the production of new clot inhibiting or dissolving substances. The award to Montagnier, who discovered the virus that causes acquired immune deficiency syndrome (AIDS), is to be used to continue his research into this and other human retroviruses. And Berridge will continue to explore the presence and function in cells of substances related to inositol trisphosphate, the work for which his share of the prize was awarded.

Peter Newmark also applied for product licences for its recombinant DNA-produced $\alpha$-interferon (Roferon A).

It remains to be seen, said Wellcome officials last week, whether there will be conditions in which their broad-spectrum product is advantageous or disadvantageous compared with single interferons. So far, both Schering and Hoffmann-La Roche have each concentrated on only one $\alpha$-interferon. Dr Daniel Catovsky of the Royal Postgraduate School of Medicine in London, who has carried out a trial of Wellcome's interferon, said this week that it seems as if all cases of hairy-cell leukaemia seem to benefit in a predictable way from treatment.

Schering's interferon- $\alpha_{2 \mathrm{~b}}$ started life as a clone in Dr Charles Weissmann's laboratory at the University of Zurich and was developed by Biogen for Schering, which now has a variety of product licences in the Philippines, Belgium and Ireland but none yet in the United States. HoffmannLa Roche's interferon- $\alpha_{2 \mathrm{a}}$ was originally cloned by Genentech.

In contrast with its policy on interferon, Genentech has chosen to be much more independent with TPA, although it does have marketing agreements with some overseas companies. From the first cloning of TPA's DNA at Genentech in 1982 (starting with a TPA-producing cell line characterized by Dr Désiré Collen, see below), the company had reached the stage last year of converting a car park into a fermentation plant dedicated to the culture of the mammalian cells that produce TPA after its DNA has been genetically engineered into them; several European patents have already been granted and clinical trials are far advanced.

By contrast, Wellcome's TPA is still at preclinical stage and is far from being a home-bred product. The original cloning was carried out by Joe Sambrook at Cold Spring Harbor Laboratory in conjunction with the Cell Biology Corporation which was a collaboration between the laboratory and Baxter Travenol. Pre-production development was carried out for Travenol by the biotechnology company Genetics Institute, based in Cambridge, Massachusetts. And Wellcome then took over for the production stages, because of its expertise in the large-scale culture of mammalian cells gained during its interferon work.

The hope is that TPA will be a better thrombolytic agent, particularly in the removal of clots in the coronary arteries, than the currently favoured streptokinase. Commenting on the clinical trials in New England Journal of Medicine last October, Dr Sol Sherry of Temple University School of Medicine concluded that "se-
Plutonium dumping?

REPORTS of plutonium on the seabed near the Loviisa nuclear power station in Finland have been greatly exaggerated, according to ErkkeIkusof the Finnish Centre for Radiation and Nuclear Safety. But the reports have come at an embarrassing moment for Finland's nuclear energy industry. The two nuclear power companies, Teollisuuden Voima (TVO), which has two nuclear power stations at Olkiluoto, and Imatram Voima (IVO), which operates the two stations at Loviisa, are at present negotiating a cooperation arrangement in order to increase their combined generating capacity by $1,000 \mathrm{MW}$.

According to Ikus, the Centre for Radiation and Nuclear Safety monitors the whole Finnish coastline, but concentrates, naturally, on the vicinity of Olkiluoto and Loviisa. The reports about Loviisa referred, he said, to a plutonium concentration of about 100-300 becquerels per $\mathrm{m}^{2}$, which, he said, is "typical for all our coastal stations". Helsinki radio, which first carried the story, had, he said, simply mistaken its newsworthiness.

In any case, Ikus said, the plutonium in question came, not from Loviisa, but from the fallout from nuclear tests in the past. When asked about reports reaching Sweden from Estonian dissidents that nuclear waste from the Paltiski submarine base is being dumped in the forest near Tallinn or discharged directly into the Baltic, Ikus said that he was "sure on scientific grounds" that this was not the case with the plutonium found in the Finnish sediments.

Vera Rich

rious questions remain about how much of a therapeutic advance it will represent as compared with the agents already available". Undeterred, Genentech and Wellcome are prepared to foot the bills for what might be a protracted test case for the patentability of the products of biotechnology. "If litigation does proceed", says Stephen Crespi, controller of patents for the British Technology Group, "it will shed some much-needed light in patentability in this very untested field."

Peter Newmark

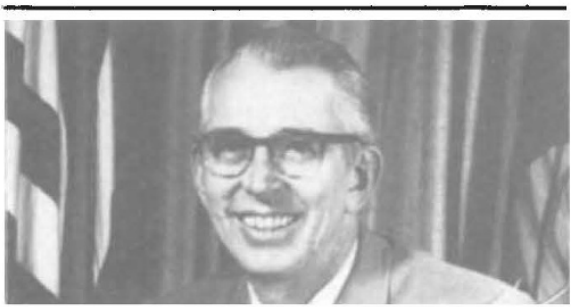

DR James C. Fletcher, administrator of the US National Aeronautics and Space Administration between 1972 and 1977 , who has been invited to resume the post in succession to $\mathrm{Mr}$ James Beggs, who has resigned. The appointment is subject to approval by the US Senate. 